\title{
Jurnal Pendidikan Fisika
}

https://journal.unismuh.ac.id/index.php/jpf

DOI: 10.26618/jpf.v9i1.4361

\section{The Effect of E-Learning Application through the Use of Whatsapp-Assisted Edmodo on the Students' Learning Outcomes in the Concept of Sound Waves}

\author{
Moh. Reghi Mamonto, Abdul Haris Odja*, Tirtawaty Abdjul \\ Physics Department, Faculty of Mathematics and Natural Sciences, Gorontalo State University, Gorontalo, 96128, \\ Indonesia \\ *Corresponding author: Abdul.haris.odja@gmail.com
}

Received: November 22, 2020; Accepted: January 25, 2021; Published: January 30, 2021

\begin{abstract}
This study aims to find out the students' learning outcomes in the application of e-learning through the use of WhatsApp-assisted Edmodo in the concept of sound waves. In addition, students' responses to the treatments given were also observed for the sake of evaluation. This research used a quasi-experimental research design carried out at SMA Negeri 1 Gorontalo in the even semester of the 2019/2020 academic year. The subject of the research was class XI IPA 8 consisting of 20 students. Tests were administered to students to obtain data of the students' learning outcomes. The data collected were then analyzed by using normality test and statistical t-test. Based on the research results, it is known that the t-value (5.53) is greater than the t-table (1.72), so $H_{0}$ is accepted and $H_{1}$ is rejected. It means that there is a significant positive effect of using whatsApp-assisted edmodo on learning outcomes in the concept of sound waves. It can be seen from the difference of mean score between the pretest and posttest scores of the experimental class. Therefore, it can be concluded that the increase in students' learning outcomes on the concept of sound waves is in the strong effect category.
\end{abstract}

Keywords: edmodo, e-learning, learning outcomes, whatsapp assistance

(C) 2021 Physics Education Department, Universitas Muhammadiyah Makassar, Indonesia.

\section{INTRODUCTION}

Educators have an important role in shaping human resources to become more qualified, so that learning in the mastery of science and technology must be better. In the learning process, there are two important things that support a quality of learning, namely methods and media. The position of learning methods and media is closely related because the main function of learning media is as a teaching aid that supports the use of learning methods used by educators.

Information Technology (IT) is able to become a media and a broad learning resource, enabling students to learn independently. The need for IT-based teaching and learning concepts and mechanisms is something that requires 
serious attention. This concept is known as elearning and it has an effect on the transformation of conventional education into digital form. This is in line with Hanum (2013) who stated that e-learning is aimed at making a transformation of the learning process in schools or colleges into a digital form connected by internet technology.

Currently the e-learning program is a hot discussion topic among educators, parents and students due to conditions and circumstances that demand the presence of elearning. According to Rusli et al. (2017), elearning is student-centered learning using electronic media or learning based on information technology or multimedia.

Since the Covid-19 pandemic that occurred around the world, all teachers have been required to carry out learning activities from home. E-learning is one that is required in the world of education from elementary to tertiary level. In general, universities have an their own e-learning system, but the activities are very limited. Gorontalo State University has been using its e-learning system through SIAT. The Covid-19 emergency response requires lecturers and students to study and carry out online learning (Arota et al., 2020).

The use of e-learning as technology also needs a plan to be able to carry out effective learning and improve students' learning outcomes. The atmosphere of e-learning will force students to play a more active role in learning because e-learning requires students to look for other learning materials or resources with their own efforts and initiatives.

The emergence of e-learning shows the various kinds of online learning media used by teachers such as google classroom, schoology, edmodo and others. Of the various kinds of learning media that exist, the writer is more interested in using edmodo as an elearning medium. Edmodo is one of the elearning media in Indonesia. It is an interactive media which is equipped with communication facilities for students and educators, among educators, and parents to be connecter each other as well as other learning resources that can be accessed by students.

Edmodo is described as using a social networking concept that resembles Facebook, so that this system has features similar to Facebook, and even almost everyone says that Edmodo is the Facebook for educational purposes. Kamarga (2011) claimed that edmodo is designed to be school-based to support the learning process. Apart from social networking among its users, edmodo is equipped with several learning activities, such as quizzes, assignments, polls, grade books, libraries, award badges, and parent code. For teaching materials, edmodo supports teaching materials in the form of files and links.

The problem around us is that the use of gadgets as information technology is underutilized in the education sector, instead it is used for things that are less useful, such as the use of online and offline games as well as excessive use of social media which is 
dominated by teenagers or students. Whatsapp as one of the most influential social media and is widely used by people in Indonesia. This is because WhatsApp messenger is an information technology application that is very easy to use as a communication tool (Sahidillah \& Miftahurrisqi, 2019).

In whatsapp messenger there is a group chat feature which is very easy to use to form an online discussion forum (anywhere and anytime). The use of whatsapp by students is only limited to communicating, and it doesn't take advantage of the sending features in the form of files, videos and teaching materials that support the learning process and increase their knowledge (Sahidillah \& Miftahurrisqi, 2019). The application of e-learning from various learning media that was used previously was rather stiff and boring, resulting in a lack of students' interest in learning during e-learning process. In this study, the learning media used are very communicative and flexible with a social media approach, namely the use of Edmodo which resembles Facebook and has features that support e-learning and is assisted by WhatsApp which is easy to use as a means of communication between educators and learners.

\section{METHODS}

The research method used in this study was an experimental method with One Group Pretest-Posttest Design. Through this design, a pretest was distributed before giving treatment and posttest after giving treatment. This research design is shown in table 1 below.

Table 1. Research design

\begin{tabular}{ccc}
\hline Pre test & Treatment & Post test \\
\hline $\mathrm{X} 1$ & $\mathrm{P}$ & $\mathrm{X} 2$
\end{tabular}

Information:

$\mathrm{X}_{1}$ : Learning outcomes before treatment

$\mathrm{P}$ : Treatment, using Whatsapp-assisted Edmodo

$\mathrm{X}_{2}$ : Learning outcomes after treatment

The treatment in this study refers to the use of Edmodo assisted by WhatsApp. The pretest and posttest were in the form of essay consisting of 11 questions related to sound wave material at the cognitive level of understanding (C2), applying (C3), and analyzing (C4). The learning aspects in the classroom can be shown in table 2 below.

Table 2. Learning aspects

\begin{tabular}{ll}
\hline \multicolumn{1}{c}{ Aspect } & \multicolumn{1}{c}{ Experiment class } \\
\hline Nature of meeting & Online \\
Learning materials & Sound waves \\
Time & 8 Hours of learning \\
Meeting & 5 times meeting \\
Learning media & Whatsapp social media \\
& and Edmodo \\
Learning tools & Laptop/computer/smartph \\
& one \\
Learning methods & $\begin{array}{l}\text { Discussion, assignment } \\
\text { and evaluation }\end{array}$ \\
\end{tabular}

\section{RESULTS AND DISCUSSION}

The results of the research obtained were tested through the hypothesis which aims to determine whether there is a positive effect of using WhatsApp-assisted Edmodo on the students' learning outcomes. In addition, we 
also analyzed the level of effectiveness of the use of WhatsApp-assisted Edmodo by using the effect size analysis which aims to determine the level of effectiveness of the treatment model or learning method that has been applied to students.

\section{A. Results \\ 1. Hypothesis testing}

Hypothesis testing aims to determine whether there is a positive effect of the treatment given on students' learning outcomes. The results of the hypothesis statistical test obtained can be seen in table 3 below.

Table 3. Hypothesis testing results

\begin{tabular}{cccc}
\hline Class & $\mathbf{T}_{\text {count }}$ & $\mathbf{T}_{\text {table }}$ & Status \\
\hline Experiment & 5.53 & 1.72 & $\begin{array}{c}\mathrm{H}_{0} \text { be } \\
\text { accepted }\end{array}$ \\
\hline
\end{tabular}

learning outcomes tests and the effect size can be seen in table 4 below.

Table 4. Recapitulation of average learning outcomes tests and effect size

\begin{tabular}{cccc}
\hline \multirow{2}{*}{ Test } & \multirow{2}{*}{ Average } & \multicolumn{2}{c}{ Effect size } \\
\cline { 3 - 4 } & & Score & Criteria \\
\hline Pretest & 43.25 & 1.56 & Strong \\
Posttest & 68.83 & & effect \\
\hline
\end{tabular}

From table 4, it can be known that the use of WhatsApp assisted Edmodo improved the students' learning outcomes with an average pretest or before treatment value of 43.25 and a posttest or after treatment value of 68.83 with an effect size value of 1.56 (Strong effect) category. The effect size value for each level of cognitive qustions can be seen in figure 1 below.
Table 3 shows the calculation of the hypothesis testing, and it is obtained that $t_{\text {count }}$ $>t_{\text {table }}$ for the level $\alpha=0.05$. Then $\mathrm{H}_{0}$ is accepted and $\mathrm{H}_{1}$ is rejected. Thus, the application of e-learning on the use of Whatsapp-assisted Edmodo has a significant positive effect on students' learning outcomes on the concept of sound waves.

\section{Effect Size}

To see the effect size of learning outcomes in the e-learning through the use of Whatsapp-assisted Edmodo, the researchers used an essay test of 11 questions with 6 indicators. The effect size can be considered as a measurement of the meaning of a study. Based on the data analysis of the pretest and posttest results at the beginning and at the end of the meeting, the average score of students'

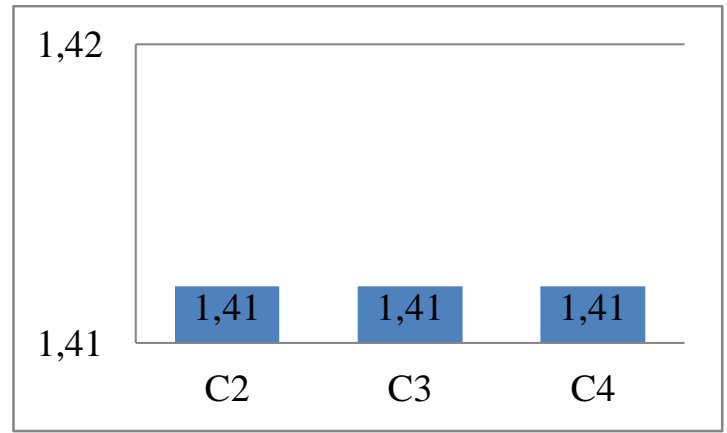

Figure 1. Effect size of each cognitive level problem

Based on Figure 1 above, the effect size of each cognitive level of questions, either $\mathrm{C} 2, \mathrm{C} 3$ or $\mathrm{C} 4$, has a value of 1.41 and this value is included in the strong effect category. Thus, the use of Whatsapp-assisted Edmodo both in terms of understanding, application and analysis of students experiences was highly effective in the e-learning. 
This effectiveness is able to provide a positive influence on students' learning outcomes, and at the same time it can be a good alternative for distance learning with a choice of communicative and flexible learning media.

\section{B. Discussion}

This research, which was conducted at SMA Negeri 1 Kota Gorontalo, aiming to see the effect of using edmodo assisted by WhatsApp on students' learning outcomes. This research provides an alternative in teaching and learning activities between teachers and students in the current Covid-19 pandemic state which requires learning from home. This distance e-learning requires internet facilities as the main factor for the smooth running of e-learning, According to Yazdi (2013), e-learning is a form of distance learning that uses electronic circuits such as the internet to convey learning content, interaction or guidance to students.

In its implementation, e-learning also requires a media or better known as a platform that can support the implementation of e-learning itself. One of the platforms that can be used in the e-learning process is edmodo. Edmodo is a positive learning environment that provides a path for interaction among students and educators in an academic atmosphere (Vera \& Nilam, 2019).

Edmodo can be used as a learning communication platform to support learners' learning at the individual, group and whole class level, both inside and outside the classroom, which can be used across formal and informal learning settings, enabling learners to collaborate, communicate, submit assignments and uploading and downloading files, and educators to share lecture notes with students, connect to useful websites, upload and download learning references for students, create online quizzes, notification news and agenda events (Kong \& Song, 2014).

An educator can easily manage a system that provides the best and practical features, so that teachers are always connected with students and manage students' activities easily. Learning activities that can be used are in accordance with the features available on edmodo, namely content sharing or sharing subject matter, assignments, quizzes, and allowing discussion activities on the comments feature. Supporting this, Al-said (2015) stated that edmodo learning can accessed via the web and smartphone (windows phone, iOS, android, etc.) online in which there is a virtual room for educators and students to discuss ideas and share files (text, images, audio, and video).

Planting concepts can be easily accepted for students if the teaching and learning process at edmodo is not preoccupied with other things such as advertisements, online games and so on. Shams et al. (2015) claimed that edmodo is a safe online learning environment and free of advertisements, 
games and other distractions that can be used to communicate between educators and students both in learning the lessons, homework, and collaborating with classmates. The results of research conducted by Al-said (2015) revealed that the edmodo learning process can create interesting, innovative and effective learning activities and can save time. In line with Al-Said, AlKathiri (2015) also suggested that using Edmodo has many challenges and good potential in learning.

\section{CONCLUSION AND SUGGESTION}

\section{A. Conclusion}

Based on the results of the research and data analysis, it can be concluded that there is a significant positive effect of the use of WhatsApp-assisted Edmodo on the students' learning outcomes. This influence is shown through the criteria for testing the hypothesis which is greater than the t-table. This means that the average value of the experimental class exceeds the minimum completeness criteria (KKM). Therefore, the effect size obtained was 1.56 that was categorizes as strong effect.

\section{B. Suggestion}

1. Lesson planning should be organized, communicative and flexible.

2. Providing more interactive learning will bring a more enjoyable learning atmosphere and is well absorbed by students.

3. Students must be given the freedom to explore other learning sources.

\section{REFERENCES}

Al-kathiri F. (2015). Beyond the classroom walls edmodo in Saudi secondary school efl instruction, attitudes and challenges. Journal Canadian Center of Science and Education, 8(1), 189204.

Al-said, K. M. (2015). Student's perceptions of edmodo and mobile learning and their real barriers towards them. The Turkish Online Jurnal of Educationnal Technology, 14(2), 167-180.

Arota, A. S., Mursalin \& Odja, A. H. (2020). The effectiveness of e-learning based on SETS to improve students' critical thinking skills in optical instrument material. Journal of physics: Conference Series. Conf. Ser. 1521 022062.

Hanum, N. S. (2013). Keefetifan e-learning sebagai media pembelajaran (Studi evaluasi model pembelajaran elearning SMK Telkom Sandhy Putra Purwokerto). Jurnal Pendidikan Vokasi, 3(1), 90-101.

Kamarga, H. (2011). Constructing online based history learning: Comparison of learning content management system (LCMS) to learning management system (LMS). HISTORIA: International Journal of History Education, 12(2), 255-273.

Kong, S. C., \& Song, Y. (2014). The impact of a principle-based pedagogical design on inquiry-based learning in a seamless learning environment in Hong Kong. Educational Technology \& Society, 17(2), 127-141.

Rusli, M., Hermawan, D., \& Supuwiningsih, N. N. (2017). Multimedia 
pembelajaran yang inovatif: Prinsip dasar dan model pengembangan. Yogyakarta: Penerbit Andi.

Sahidillah, Wildan, M., \& Miftahrrisqi, P. (2019). Whatsapp as a digital media for student literacy. Varia Education, 31(1), 52-57.

Shams-Abadi, B. B., Ahmadi, S. D., \& Mehrdad, A.G. (2015). The effect of edmodo on efl learner's writing performance. International Journal of
Educational Investigations, 2(2), 8897.

Vera, D. K. O., \& Nilam, S. (2019). The effectiveness of using edmodo-based e-learning on mathematics communication skills. Jurnal Curere, $3(2), 58-65$.

Yazdi, M. (2013). E-Learning sebagai media pembelajaran interaktif berbasis eknologi informasi. Jurnal Ilmiah Foristek, 2(1), 143-152. 